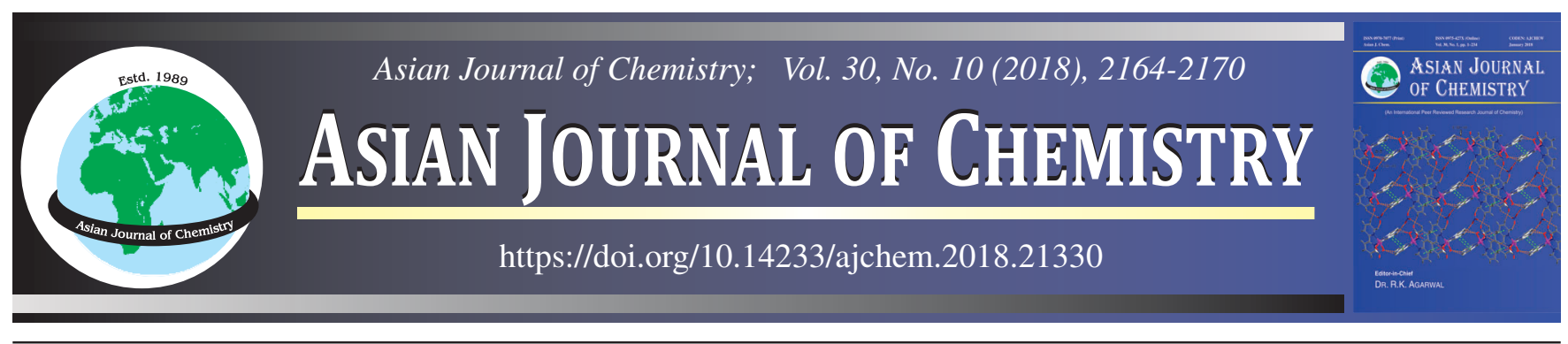

\title{
Quinazolinone Platinum Metal Complexes: in silico Design, Synthesis and Evaluation of Anticancer Activity
}

\author{
Sanjay D. Sawant*, Megha Sahu and Amit G. Nerkar
}

Department of Pharmaceutical Chemistry, Sinhgad Technical Education Society's, Smt. Kashibai Navale College of Pharmacy, Kondhwa (Bk), Pune-411 048, India

*Corresponding author: E-mail: principal.skncop@sinhgad.edu

Received: 13 March 2018;

Accepted: 30 May 2018;

Published online: 31 August 2018;

AJC-19037

Dihydrofolate reductase (DHFR) has been explored as a target for the development of agents for wide variety of human diseases, including cancer, autoimmune and infectious diseases. Several metal complexes are being used in management of cancer. The square planar Pt(II) complex, cis $\mathrm{PtCl}_{2}\left(\mathrm{NH}_{3}\right)_{2}$ turned out to be even more effective at forcing filamentous growth. Cisplatin is an inorganic heavy metal complex that has activity similar to cell-cycle-phase-nonspecific alkylating agents such as cyclophosphamide and some other $\mathrm{Ni}$ and $\mathrm{Cu}$ metal complexes. It produces intrastrand DNA cross-link and form DNA adducts, thus inhibiting the synthesis of DNA, RNA and proteins preferentially. in silico Screening of platinum metal complexes was performed by Vlife MDS 4.3 software. In this procedure, selection of molecule, selection of PDB, optimization of PDB and docking of molecules was carried out. Synthesis of metal complexes was done by multi component reaction method. Platinum metal complexes of quinazolinone Schiff bases prioritized by in silico studies were characterized by IR, TLC, NMR, XRD, FESEM and some physico-chemical parameters. Prioritized molecules were further evaluated by in vitro anticancer cell line assay on ten cell lines with adriamycin as standard. The results showed that the platinum metal complexes of qunazolinone Schiff bases can be potential anticancer agents through DHFR inhibitory mechanism.

Keywords: Platinum, Dihydrofolate reductase, Cisplatin, Autoimmune disease, Methotrexate.

\section{INTRODUCTION}

Cancer is one of the leading causes of mortality worldwide as $12 \%$ of all deaths are due to cancer [1]. Its cases in the developed countries are more and rate of mortality occupies the second rank in the order of death causes [2]. In next 20 years, numbers of cancer deaths are expected increase from about 6 to 10 millions per annum. Similar tendency may be observed in the developing countries too [3]. The dihydrofolate reductase, thioredoxin reductase (TrxR) [4] and thymidylate synthase [5] enzymes are involved in the process of tumor cell proliferation, cell growth and survival. These enzymes use NADPH as electron donor to reduce dihydrofolate to tetrahydrofolate. Tetrahydrofolate and its derivatives serve as 1-C donors in purine synthesis and thereby nucleic acid synthesis, essential for cell proliferation and cell growth [6]. Quinazolinone containing drugs such as methotrexate, trimetrexate, pralatrexate, piritrexim and talotrexinare are used in the treatment of lymphocytic leukemia relapsed peripheral T-cell lymphoma and leukemia [7]. Dihydrofolate reductase (DHFR; tetrahydrofolate dehydrogenase; 5,6,7,8-tetrahydrofolate-NADP oxidoreductase; EC 1.5.1.3) plays an important role in conversion of deoxyribouridine into thymine and also down regulate folic acid. Both the bio molecules are vital for cell growth and cell division. Overall, inhibition of hDHFR in cancerous cell affects essential step for nucleic acid synthesis and hence inhibit the growth as well as division of cancerous cells. Metal complexes are used to target the redox balance in cancer cells, one of the highly effective strategies for cancer treatment. This multiple-site approach also helps for offering selectivity over normal cells [8]. Platinum complexes have been found effective in cancer chemotherapy, since their entry in the late 1970s in clinical practice. The metallo-elements [9] present in trace quantities play vital roles at the molecular level in living system. The transition metal ions are responsible for the functioning of different enzymes [10]. Methotrexate (MTX)

This is an open access journal, and articles are distributed under the terms of the Creative Commons Attribution-NonCommercial 4.0 International (CC BY-NC 4.0) License, which allows others to copy and redistribute the material in any medium or format, remix, transform, and build upon the material, as long as appropriate credit is given and the new creations are licensed under the identical terms. 
contains a 2,4-diaminopteridine ring and $N, N$-dimethyl- $p$ aminobenzoic acid residue linked with glutamic acid by a peptide bond. In aqueous solution, it exists in fully protonated form as a $\mathrm{H}_{3} \mathrm{~L}$ ligand [11]. The main objectives for drug design were to achieve relative safety, circumvention of resistance and improvement on the spectrum of activity of the proposed metal complexes. in silico screening of compounds was carried out using Vlife MDS 4.3 software. Quinazoline metal complex derivatives were synthesized through bromination, esterification, ring formation by formamide at $120{ }^{\circ} \mathrm{C}$, Schiff base synthesis and finally, lead molecules were synthesized by coordination metal complex formation. These compounds were characterized by IR, NMR, XRD, FESEM studies. in vitro cytotoxicity study was performed on 10 human cell lines in ACTREC, Navi Mumbai with adiramycin as standard drug for comparison.

\section{EXPERIMENTAL}

Docking simulation: Computer-assisted simulated docking experiments were carried out in V-life MDS 4.3 for prioritized molecules. Validation of protein subunit was done by the online server [12]. Protein data bank (PDB: 1S3V) contains structural information of the macromolecules determined by X-ray crystallography and NMR spectroscopy [13]. Two dimensional structures of ligand were prepared in ChemDraw or Marvin sketch and converted to 3D by Vlife sciences MDS 4.3. The 3D structures were energetically minimized using Merck Molecular Force Field (MMFF). Conformers of the compounds were generated by Monte Carlo method. All the Conformers were then energetically minimized up to the RMS gradient of 0.01. MMFF was used for optimizing molecules. Parameters used were MMFF, Gasteiger Marsili charge and dielectric properties were kept constant. Library of ligands containing 40 molecules were designed as shown in Table- 1 .

All chemicals were purchased from Sigma Aldrich, Merck, Spectrochem and Research Laboratory of laboratory grade and analytical grade. Column chromatography was performed for purification of compounds on Spectrochem silica gel (60-120 mesh). TLCs were carried out on pre-coated silica gel, $\mathrm{GF}_{254}$ aluminium sheets (Merck 5554). Melting points were determined in open capillary on Veego (India) electronic apparatus and are uncorrected. FT-IR spectra were recorded on Shimadzu FTIR Affinity-1 instrument with disk pellet method using potassium bromide. The ${ }^{1} \mathrm{H}$ NMR (300 $\mathrm{MHz}$ ) spectra were recorded on a Bruker $500 \mathrm{MHz}$; Model: Advance III HD, in $\mathrm{CDCl}_{3}$ and DMSO in CIF Center, Savitribai Phule University, Pune. FESEM- EDS were performed on Bruker XFlash $6 \mathrm{I} 30$ and element detection range from ${ }^{4} \mathrm{Be}$ to ${ }^{95} \mathrm{Am}$. This method basically used for quantification analysis of metals in synthesized complex from CIF, Savitribai Phule University of Pune, Pune, India.

\section{Synthesis of Schiff bases}

Synthesis of 3-(2-substituted benzylideneamino)-2substituted quinazolin-4(3H)-one (3) [14-17]: Anthranilic acid (1) (12 g, $0.1 \mathrm{~mol})$ was dissolved in glacial acetic acid and cooled at $0{ }^{\circ} \mathrm{C}$. Then bromine in acetic acid was added, till the reddish-brown colour of the bromine persisted. Before this point was reached, the mixture was converted into thick mass of white glistening crystals of hydro bromides of the bromo anthranilic acids. The product was filtered, washed with benzene and dried. It was then boiled with dilute hydrochloric acid and filtered while hot under suction. The insoluble residue was extracted twice with boiling water. The filtrate, upon cooling yielded an abundant precipitate of the bromo anthranilic-acid (2).

Antranilic acid/bromo anthanilic acid (2) (1 eq) $1 \mathrm{~g} 0.007$ mol was dissolved in pyridine and reaction was maintained at $0{ }^{\circ} \mathrm{C}$. Then benzoyl chloride ( $\left.1 \mathrm{eq}\right)(0.84 \mathrm{~mL}, 0.007) \mathrm{mol}$ was added drop wise. The reaction mixture was stirred for 3-4 h. While ice cold water was added, white precipitate of 2-phenyl$4 H$-benzo[d][1,3]oxazin-4-one (3) was obtained, filtered and washed with cool water to remove pyridine.

A suspension of ethyl 2-amino-5-bromobenzoate (2) $(0.500 \mathrm{~g}, 2.048 \mathrm{mmol})$ in formamide $(1.225 \mathrm{~mL}, 30.7 \mathrm{mmol})$ was refluxed at $120{ }^{\circ} \mathrm{C}$ for $4 \mathrm{~h}$. Reaction was monitored by TLC using $50 \%$ ethyl acetate in petrolium ether as mobile phase. After the complete conversion of starting material, reaction mixture was cooled to room temperature to form crystalline precipitate. Reaction mixture was poured on ice-cold water and then solid formed was filtered out as 6-bromoquinazolin-4(3H)-one (3) (0.218 g), $0.969 \mathrm{mmol}$.

Antranilic acid/bromoanthanilic acid (2) (1.08 g) was dissolved in DMSO (3 mL). Then $\mathrm{KOH}(1.5 \mathrm{eq})$ and $\mathrm{CS}_{2}$ $(0.5 \mathrm{~mL})$ was added [18]. The reaction mixture was refluxed at $110^{\circ} \mathrm{C}$ for $3-4 \mathrm{~h}$ with continuous stirring. Reaction mixture was then neutralized with dil. sulphuric acid to form product 3 . The product was separated by vacuum filtration.

2-Phenyl-4H-benzo[d][1,3] oxazin-4-one (1 eq) $2.5 \mathrm{~g}$, $0.015 \mathrm{~mol}$ was dissolved in pyridine, then hydrazine hydrate ( 2 eq) $1.5 \mathrm{~mL}, 0.031 \mathrm{~mol}$ was added. The reaction mixture was refluxed for 3-4 $\mathrm{h}$ and reaction was monitored by TLC. Ice cold water was added to precipitate out white solid product 4. It was filtered and washed with cool water to remove pyridine.

Synthesis of 3-(2-substituted benzylideneamino)-2phenylquinazolin-4(3H)-one: To hot ethanolic solution of 2amino 3-phenyl quinazolin 4-one (4) $0.5 \mathrm{~g}(0.002 \mathrm{~mol})$ (1 eq), hot ethanolic solution of substitued benzaldehyde (1 eq) was added and 2-3 drops of $\mathrm{H}_{2} \mathrm{SO}_{4}$ were subsequently added. The reaction mixture was then refluxed with stirring for $1 \mathrm{~h}$ to form solid mass 5 . The product was separated by vacuum filtration.

Synthesis of 3-(2-substituted benzylideneamino)-2phenylquinazolin-4(3H)-one platinum metal complex [19]: Calculated amount of quinazolinone Schiff base 5 (1.2 eq) was dissolved in hot ethanol. To this solution; calculated amount of metal salt $(1.1 \mathrm{eq})\left[\left(\mathrm{PtCl}_{2} \cdot 2 \mathrm{H}_{2} \mathrm{O}\right)\right.$ was added with continuous stirring. The reaction mixture was refluxed with continuous stirring for 2-3 h. On cooling, complex 6 was precipitated out (Scheme-I). It was then washed with aqueous ethanol and dried under vacuum. The details of 12 Schiff bases and synthesized metal complexes are given in Tables 2 and 3, respectively.

in vitro Cytotoxicity assay: in vitro cytotoxicity of the synthesized compounds were performed at ACTREC, Navi Mumbai, against 10 Human Cancer Cell lines i.e. A549 (lungs), K562 (lukemia), MCF7 (breast), SiHa (cervix), KB (nesophayn- 
TABLE-1

DOCKING SCORES OF MOLECULES

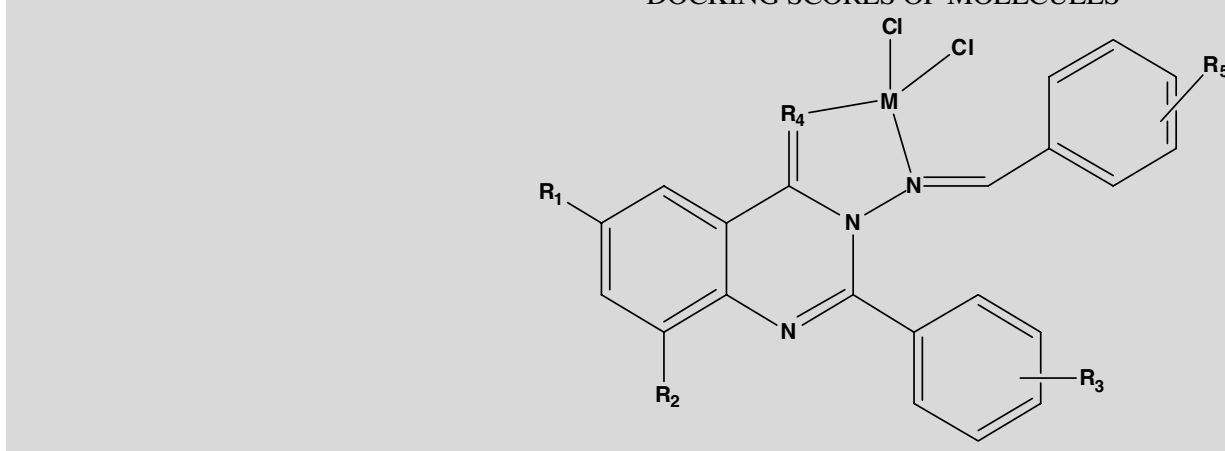

\begin{tabular}{|c|c|c|c|c|c|c|c|c|}
\hline S. No. & Code & $\mathrm{R}_{1}$ & $\mathrm{R}_{2}$ & $\mathrm{R}_{3}$ & $\mathrm{R}_{4}$ & $\mathrm{R}_{5}$ & $\mathrm{M}$ & Docking score \\
\hline 1 & SM-01 & $-\mathrm{H}$ & $-\mathbf{H}$ & $-\mathrm{C}_{6} \mathrm{H}_{5}$ & $\mathrm{O}$ & $p-\mathrm{OCH}_{3}$ & $\mathrm{Pt}(\mathrm{II}) \mathrm{Cl}_{2}$ & -80.254 \\
\hline 2 & SM-02 & $-\mathrm{I}$ & $-\mathrm{I}$ & $-\mathrm{C}_{6} \mathrm{H}_{5}$ & $\mathrm{O}$ & $p-\mathrm{OCH}_{3}$ & $\mathrm{Pt}(\mathrm{II}) \mathrm{Cl}_{2}$ & -50.369 \\
\hline 3 & SM-03 & $-\mathrm{Br}$ & $-\mathrm{Br}$ & $-\mathrm{C}_{6} \mathrm{H}_{5}$ & $\mathrm{O}$ & $p-\mathrm{OCH}_{3}$ & $\mathrm{Pt}(\mathrm{II}) \mathrm{Cl}_{2}$ & -63.551 \\
\hline 4 & SM-04 & $-\mathrm{I}$ & $-\mathrm{H}$ & $-\mathrm{C}_{6} \mathrm{H}_{5}$ & $\mathrm{O}$ & $p-\mathrm{OCH}_{3}$ & $\mathrm{Pt}(\mathrm{II}) \mathrm{Cl}_{2}$ & -49.373 \\
\hline 5 & SM-05 & $-\mathrm{Br}$ & $-\mathbf{H}$ & $-\mathrm{C}_{6} \mathrm{H}_{5}$ & $\mathbf{O}$ & $p-\mathrm{OCH}_{3}$ & $\mathrm{Pt}(\mathrm{II}) \mathrm{Cl}_{2}$ & -53.925 \\
\hline 6 & SM-06 & $-\mathbf{H}$ & $-\mathbf{H}$ & $-\mathrm{C}_{6} \mathrm{H}_{5}$ & S & $p-\mathrm{OCH}_{3}$ & $\operatorname{Pt}(\mathrm{II}) \mathrm{Cl}_{2}$ & -86.398 \\
\hline 7 & SM-07 & $-\mathbf{B r}$ & $-\mathbf{H}$ & $-\mathrm{C}_{6} \mathrm{H}_{5}$ & S & $p-\mathrm{OCH}_{3}$ & $\mathrm{Pt}(\mathrm{II}) \mathrm{Cl}_{2}$ & -75.556 \\
\hline 8 & SM-08 & $-\mathrm{Br}$ & $-\mathrm{Br}$ & $-\mathrm{C}_{6} \mathrm{H}_{5}$ & S & $p-\mathrm{OCH}_{3}$ & $\mathrm{Pt}(\mathrm{II}) \mathrm{Cl}_{2}$ & -66.153 \\
\hline 9 & SM-09 & $-\mathrm{I}$ & $-\mathrm{H}$ & $-\mathrm{C}_{6} \mathrm{H}_{5}$ & S & $p-\mathrm{OCH}_{3}$ & $\mathrm{Pt}(\mathrm{II}) \mathrm{Cl}_{2}$ & -66.890 \\
\hline 10 & SM-10 & $-\mathrm{I}$ & $-\mathrm{I}$ & $-\mathrm{C}_{6} \mathrm{H}_{5}$ & S & $p-\mathrm{OCH}_{3}$ & $\mathrm{Pt}(\mathrm{II}) \mathrm{Cl}_{2}$ & -54.84 \\
\hline 11 & SM-11 & $-\mathrm{H}$ & $-\mathrm{H}$ & $-\mathrm{CH}_{3}$ & $\mathrm{O}$ & $p-\mathrm{OH}$ & $\mathrm{Pt}(\mathrm{II}) \mathrm{Cl}_{2}$ & -58.821 \\
\hline 12 & SM-12 & $-\mathrm{Br}$ & $-\mathrm{H}$ & $-\mathrm{CH}_{3}$ & $\mathrm{O}$ & $p-\mathrm{OH}$ & $\mathrm{Pt}(\mathrm{II}) \mathrm{Cl}_{2}$ & -60.110 \\
\hline 13 & SM-13 & $-\mathrm{Br}$ & $-\mathrm{Br}$ & $-\mathrm{CH}_{3}$ & $\mathrm{O}$ & $p-\mathrm{OH}$ & $\mathrm{Pt}(\mathrm{II}) \mathrm{Cl}_{2}$ & -51.306 \\
\hline 14 & SM-14 & $-\mathrm{I}$ & $-\mathrm{H}$ & $-\mathrm{CH}_{3}$ & $\mathrm{O}$ & $p-\mathrm{OH}$ & $\mathrm{Pt}(\mathrm{II}) \mathrm{Cl}_{2}$ & -57.164 \\
\hline 15 & SM-15 & $-I$ & $-I$ & $-\mathrm{CH}_{3}$ & $\mathrm{O}$ & $p$-ОН & $\mathrm{Pt}(\mathrm{II}) \mathrm{Cl}_{2}$ & -68.776 \\
\hline 16 & SM-16 & $-\mathbf{H}$ & $-\mathbf{H}$ & $-\mathrm{CH}_{3}$ & S & $p-\mathrm{OH}$ & $\operatorname{Pt}(\mathrm{II}) \mathrm{Cl}_{2}$ & -78.593 \\
\hline 17 & SM-17 & $-\mathrm{Br}$ & $-\mathrm{H}$ & $-\mathrm{CH}_{3}$ & S & $p-\mathrm{OH}$ & $\mathrm{Pt}(\mathrm{II}) \mathrm{Cl}_{2}$ & -60.035 \\
\hline 18 & SM-18 & $-\mathrm{Br}$ & $-\mathrm{Br}$ & $-\mathrm{CH}_{3}$ & S & $p-\mathrm{OH}$ & $\mathrm{Pt}(\mathrm{II}) \mathrm{Cl}_{2}$ & -61.927 \\
\hline 19 & SM-19 & $-I$ & $-\mathrm{H}$ & $-\mathrm{CH}_{3}$ & S & $p-\mathrm{OH}$ & $\mathrm{Pt}(\mathrm{II}) \mathrm{Cl}_{2}$ & -60.426 \\
\hline 20 & SM-20 & $-\mathrm{I}$ & $-\mathrm{I}$ & $-\mathrm{CH}_{3}$ & S & $p-\mathrm{OH}$ & $\mathrm{Pt}(\mathrm{II}) \mathrm{Cl}_{2}$ & -62.205 \\
\hline 21 & SM-21 & $-\mathbf{H}$ & $-\mathbf{H}$ & $-\mathrm{C}_{6} \mathrm{H}_{5}$ & $\mathrm{O}$ & $p$-ОH & $\mathrm{Pt}(\mathrm{II}) \mathrm{Cl}_{2}$ & -80.094 \\
\hline 22 & SM-22 & $-\mathrm{Br}$ & $-\mathrm{H}$ & $-\mathrm{C}_{6} \mathrm{H}_{5}$ & $\mathrm{O}$ & $p-\mathrm{OH}$ & $\mathrm{Pt}(\mathrm{II}) \mathrm{Cl}_{2}$ & -53.926 \\
\hline 23 & SM-23 & $-\mathrm{Br}$ & $-\mathrm{Br}$ & $-\mathrm{C}_{6} \mathrm{H}_{5}$ & $\mathrm{O}$ & $p-\mathrm{OH}$ & $\mathrm{Pt}(\mathrm{II}) \mathrm{Cl}_{2}$ & -63.992 \\
\hline 24 & SM-24 & $-\mathrm{I}$ & $-\mathrm{H}$ & $-\mathrm{CH}_{3}$ & $\mathrm{O}$ & $p-\mathrm{OH}$ & $\mathrm{Pt}(\mathrm{II}) \mathrm{Cl}_{2}$ & -49.373 \\
\hline 25 & SM-25 & $-\mathrm{I}$ & $-I$ & $-\mathrm{CH}_{3}$ & $\mathrm{O}$ & $p-\mathrm{OH}$ & $\mathrm{Pt}(\mathrm{II}) \mathrm{Cl}_{2}$ & -50.369 \\
\hline 26 & SM-26 & $-H$ & $-\mathbf{H}$ & $-\mathrm{C}_{6} \mathrm{H}_{5}$ & S & $p-\mathrm{OH}$ & $\mathrm{Pt}(\mathrm{II}) \mathrm{Cl}_{2}$ & -86.398 \\
\hline 27 & SM-27 & $-\mathrm{Br}$ & $-H$ & $-\mathrm{C}_{6} \mathrm{H}_{5}$ & S & $p-\mathrm{OCH}_{3}$ & $\mathrm{Pt}(\mathrm{II}) \mathrm{Cl}_{2}$ & -75.556 \\
\hline 28 & SM-28 & $-\mathrm{Br}$ & $-\mathrm{Br}$ & $-\mathrm{C}_{6} \mathrm{H}_{5}$ & S & $p-\mathrm{OH}$ & $\mathrm{Pt}(\mathrm{II}) \mathrm{Cl}_{2}$ & -66.153 \\
\hline 29 & SM-29 & $-\mathrm{I}$ & $-\mathrm{H}$ & $-\mathrm{C}_{6} \mathrm{H}_{5}$ & S & $p-\mathrm{OH}$ & $\mathrm{Pt}(\mathrm{II}) \mathrm{Cl}_{2}$ & -66.890 \\
\hline 30 & SM-30 & $-\mathrm{I}$ & $-\mathrm{I}$ & $-\mathrm{C}_{6} \mathrm{H}_{5}$ & $S$ & $p-\mathrm{OH}$ & $\mathrm{Pt}(\mathrm{II}) \mathrm{Cl}_{2}$ & -54.799 \\
\hline 31 & SM-31 & $-B r$ & $-\mathbf{H}$ & $-\mathrm{CH}_{3}$ & O & $p$-ОН & $\mathrm{Pt}(\mathrm{II}) \mathrm{Cl}_{2}$ & -69.544 \\
\hline 32 & SM-32 & $-\mathbf{H}$ & $-\mathbf{H}$ & $-\mathrm{CH}_{3}$ & $\mathrm{O}$ & p-OH & $\mathrm{Pt}(\mathrm{II}) \mathrm{Cl}_{2}$ & -88.168 \\
\hline 33 & SM-33 & $-\mathrm{Br}$ & $-\mathrm{Br}$ & $-\mathrm{CH}_{3}$ & $\mathrm{O}$ & $p-\mathrm{OH}$ & $\mathrm{Pt}(\mathrm{II}) \mathrm{Cl}_{2}$ & -67.885 \\
\hline 34 & SM-34 & $-\mathbf{I}$ & $-\mathbf{H}$ & $-\mathrm{CH}_{3}$ & $\mathrm{O}$ & $p-\mathrm{OH}$ & $\mathrm{Pt}(\mathrm{II}) \mathrm{Cl}_{2}$ & -86.513 \\
\hline 35 & SM-35 & $-\mathrm{I}$ & $-\mathrm{I}$ & $-\mathrm{CH}_{3}$ & $\mathrm{O}$ & $p-\mathrm{OH}$ & $\mathrm{Pt}(\mathrm{II}) \mathrm{Cl}_{2}$ & -67.384 \\
\hline 36 & SM-36 & $-\mathbf{H}$ & $-\mathbf{H}$ & $-\mathrm{CH}_{3}$ & $S$ & p-OH & $\mathrm{Pt}(\mathrm{II}) \mathrm{Cl}_{2}$ & -89.789 \\
\hline 37 & SM-37 & $-\mathrm{Br}$ & $-\mathbf{H}$ & $-\mathrm{CH}_{3}$ & $S$ & p-OH & $\mathrm{Pt}(\mathrm{II}) \mathrm{Cl}_{2}$ & -77.315 \\
\hline 38 & SM-38 & $-\mathrm{Br}$ & $-\mathrm{Br}$ & $-\mathrm{CH}_{3}$ & S & $p-\mathrm{OH}$ & $\mathrm{Pt}(\mathrm{II}) \mathrm{Cl}_{2}$ & -62.550 \\
\hline 39 & SM-39 & $-\mathrm{I}$ & $-\mathrm{H}$ & $-\mathrm{CH}_{3}$ & $S$ & $p-\mathrm{OH}$ & $\mathrm{Pt}(\mathrm{II}) \mathrm{Cl}_{2}$ & -64.020 \\
\hline 40 & SM-40 & $-\mathbf{I}$ & $-I$ & $-\mathrm{CH}_{3}$ & $S$ & $p-\mathrm{OH}$ & $\mathrm{Pt}(\mathrm{II}) \mathrm{Cl}_{2}$ & -70.665 \\
\hline 41 & \multicolumn{4}{|c|}{ Methotrexate } & & & & -50.040 \\
\hline
\end{tabular}

*Highlighted compounds show good docking scores and further prioritized for synthesis.

geal), HCT15 (colon), SK-OV-3 (ovarian), HeLa (cervix), SKMEL-2 (melanoma) and DU-145 (prostate) with adiramycin as standard [20]. in vitro cytotoxicity against human cancer cell lines was determined using 96-well tissue culture plates [21]. The $100 \mu \mathrm{L}$ of cell suspension was added to each well of the 96-well tissue culture plate. The cells were allowed to grow in carbon dioxide incubator $\left(37{ }^{\circ} \mathrm{C}, 5 \% \mathrm{CO}_{2}, 90 \% \mathrm{RH}\right)$ for
$24 \mathrm{~h}$. Test materials $(100 \mu \mathrm{L})$ were added after $24 \mathrm{~h}$ of incubation to the wells containing cell suspension. The plates were further incubated for $48 \mathrm{~h}$ in a carbon dioxide incubator. The cell growth was stopped by gently layering trichloroacetic acid $(50 \%, 50 \mu \mathrm{L})$ on top of the medium in all the wells. The plates were incubated at $4{ }^{\circ} \mathrm{C}$ for $1 \mathrm{~h}$ to fix the cells attached to the bottom of the wells. The liquid of all the wells was gently 


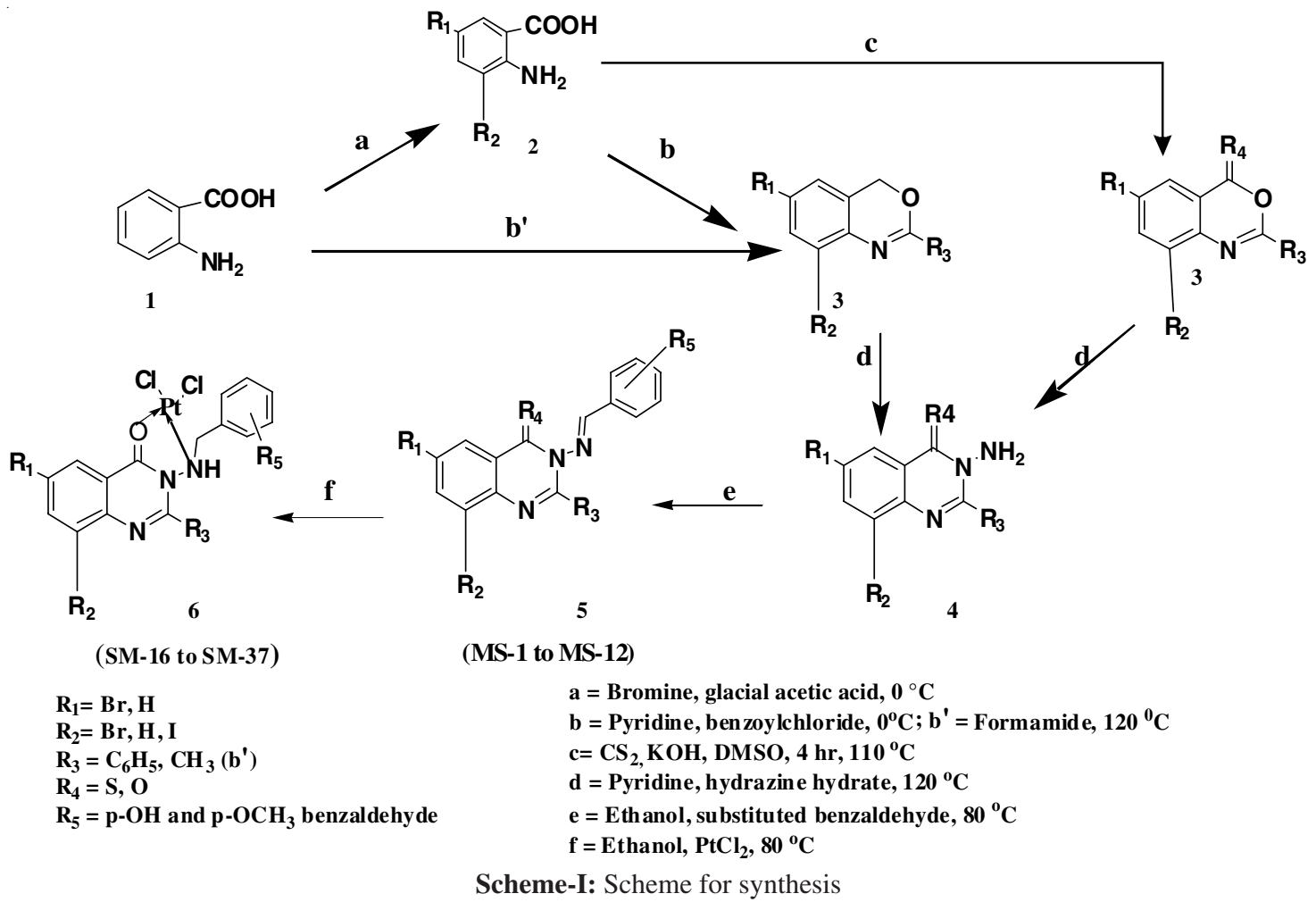

TABLE-2

SERIES OF QUINAZOLINONE SCHIFF BASES

\begin{tabular}{ccccccc}
\hline S. No. & Code & $\mathrm{R}_{1}$ & $\mathrm{R}_{2}$ & $\mathrm{R}_{3}$ & $\mathrm{R}_{4}$ & $\mathrm{R}_{5}$ \\
\hline 1 & $\mathrm{MS}-01$ & $-\mathrm{H}$ & $-\mathrm{H}$ & $-\mathrm{C}_{6} \mathrm{H}_{5}$ & $\mathrm{O}$ & $p-\mathrm{OCH}_{3}$ \\
2 & $\mathrm{MS}-02$ & $-\mathrm{Br}$ & $-\mathrm{H}$ & $-\mathrm{C}_{6} \mathrm{H}_{5}$ & $\mathrm{O}$ & $p-\mathrm{OCH}_{3}$ \\
3 & $\mathrm{MS}-03$ & $-\mathrm{H}$ & $-\mathrm{H}$ & $-\mathrm{C}_{6} \mathrm{H}_{5}$ & $\mathrm{~S}$ & $p-\mathrm{OCH}_{3}$ \\
4 & $\mathrm{MS}-04$ & $-\mathrm{Br}$ & $-\mathrm{H}$ & $-\mathrm{C}_{6} \mathrm{H}_{5}$ & $\mathrm{~S}$ & $p-\mathrm{OCH}_{3}$ \\
5 & $\mathrm{MS}-05$ & $-\mathrm{H}$ & $-\mathrm{H}$ & $-\mathrm{CH}_{3}$ & $\mathrm{~S}$ & $p-\mathrm{OH}$ \\
6 & $\mathrm{MS}-06$ & $-\mathrm{H}$ & $-\mathrm{H}$ & $-\mathrm{C}_{6} \mathrm{H}_{5}$ & $\mathrm{O}$ & $p-\mathrm{OH}$ \\
7 & $\mathrm{MS}-07$ & $-\mathrm{H}$ & $-\mathrm{H}$ & $-\mathrm{C}_{6} \mathrm{H}_{5}$ & $\mathrm{~S}$ & $p-\mathrm{OH}$ \\
8 & $\mathrm{MS}-08$ & $-\mathrm{Br}$ & $-\mathrm{H}$ & $-\mathrm{C}_{6} \mathrm{H}_{5}$ & $\mathrm{~S}$ & $p-\mathrm{OH}$ \\
9 & $\mathrm{MS}-09$ & $-\mathrm{H}$ & $-\mathrm{H}$ & $-\mathrm{CH}_{3}$ & $\mathrm{O}$ & $p-\mathrm{OH}$ \\
10 & $\mathrm{MS}-10$ & $-\mathrm{Br}$ & $-\mathrm{H}$ & $-\mathrm{CH}_{3}$ & $\mathrm{O}$ & $p-\mathrm{OH}$ \\
11 & $\mathrm{MS}-11$ & $-\mathrm{H}$ & $-\mathrm{H}$ & $-\mathrm{CH}_{3}$ & $\mathrm{~S}$ & $p-\mathrm{OH}$ \\
12 & $\mathrm{MS}-12$ & $-\mathrm{Br}$ & $-\mathrm{H}$ & $-\mathrm{CH}_{3}$ & $\mathrm{~S}$ & $p-\mathrm{OH}$ \\
\hline
\end{tabular}

pipetted out and discarded. The plates were washed five times with distilled water to remove trichloroacetic acid, growth medium, low molecular weight metabolites, serum proteins etc. and air-dried. The plates were stained with sulforhodamine B dye $(0.4 \%$ in $1 \%$ acetic acid, $100 \mu \mathrm{L})$ for $30 \mathrm{~min}$. The plates were washed five times with $1 \%$ acetic acid and then airdried. The adsorbed dye was dissolved in Tris-HCl Buffer (100 $\mu \mathrm{L}, 0.01 \mathrm{M}, \mathrm{pH} 10.4$ ) and plates were gently stirred for $10 \mathrm{~min}$ on a mechanical stirrer. The optical density was recorded on ELISA reader at $540 \mathrm{~nm}$. The cell growth was determined by subtracting mean OD value of respective blank from the mean
OD value of experimental set. Percent growth in presence of test material was calculated considering the growth in absence of any test material as $100 \%$ and in turn percent growth inhibition in presence of test material was calculated [22].

\section{RESULTS AND DISCUSSION}

in silico study of prioritized compound: For in silico studies, 40 molecules were designed on the basis of diversity in the quinazolinone scaffold. These 40 molecules were docked in the binding site of bare DHFR protein in the Vlife MDS 4.3 interface. Docking results are tabulated in Table-1 for all the designed compounds as well as methotrexate as standard drug. From the docking results on the basis of best docking scores, five top molecules were prioritized. Tables 2 and 3 show that 12 Schiff bases and 5 platinum metal complexes possess good bind affinity with selected protein. It was observed that the carbonyl groups present in these compounds is the site of binding to the receptor. Methyl or benzyl substituents were found most favourable which resulted in lowering of binding free energy in terms of docking score. Receptor was docked with the modified compounds and standard. Docking scores for most prominently active compounds were lower than -50 $\mathrm{k} / \mathrm{cal}$ mol viz. methotrexate (-50.04), SM-16 (-78.59), SM-27 (-75.55), SM-31 (-69.54), SM-36 (-89.78), SM-37 (-77.31). Metal complexes showed interaction with amino acids are

\begin{tabular}{|c|c|c|c|c|c|c|c|}
\hline \multicolumn{8}{|c|}{$\begin{array}{c}\text { TABLE-3 } \\
\text { SERIES OF QUINAZOLINONE PLATINUM COMPLEXES }\end{array}$} \\
\hline S. No. & Compound & $\mathrm{R}_{1}$ & $\mathrm{R}_{2}$ & $\mathrm{R}_{3}$ & $\mathrm{R}_{4}$ & $\mathrm{R}_{5}$ & $\operatorname{Metal}(\mathrm{Mt})$ \\
\hline 1 & SM-16 & $-\mathrm{H}$ & $-\mathrm{H}$ & $-\mathrm{CH}_{3}$ & $\mathrm{~S}$ & $p-\mathrm{OH}$ & $\mathrm{Pt}(\mathrm{II}) \mathrm{Cl}_{2}$ \\
\hline 2 & SM-27 & $-\mathrm{Br}$ & $\mathrm{H}$ & $-\mathrm{C}_{6} \mathrm{H}_{5}$ & S & $p-\mathrm{OCH}_{3}$ & $\mathrm{Pt}(\mathrm{II}) \mathrm{Cl}_{2}$ \\
\hline 3 & SM-31 & $-\mathrm{Br}$ & $\mathrm{H}$ & $-\mathrm{CH}_{3}$ & $\mathrm{O}$ & $p-\mathrm{OH}$ & $\mathrm{Pt}(\mathrm{II}) \mathrm{Cl}_{2}$ \\
\hline 4 & SM-36 & $-\mathrm{H}$ & $\mathrm{H}$ & $-\mathrm{CH}_{3}$ & $\mathrm{~S}$ & $p-\mathrm{OH}$ & $\mathrm{Pt}(\mathrm{II}) \mathrm{Cl}_{2}$ \\
\hline 5 & SM-37 & $-\mathrm{Br}$ & $\mathrm{H}$ & $-\mathrm{CH}_{3}$ & $\mathrm{~S}$ & $p-\mathrm{OH}$ & $\mathrm{Pt}(\mathrm{II}) \mathrm{Cl}_{2}$ \\
\hline
\end{tabular}


ILE7A, LEU 22A, PHE31A, ALA9A, whereas methotrexate showed same interaction with all amino acids but it also shows interaction with SER59A and THR56A. Fig. 1 shows the amino acid interaction of compound SM-16.

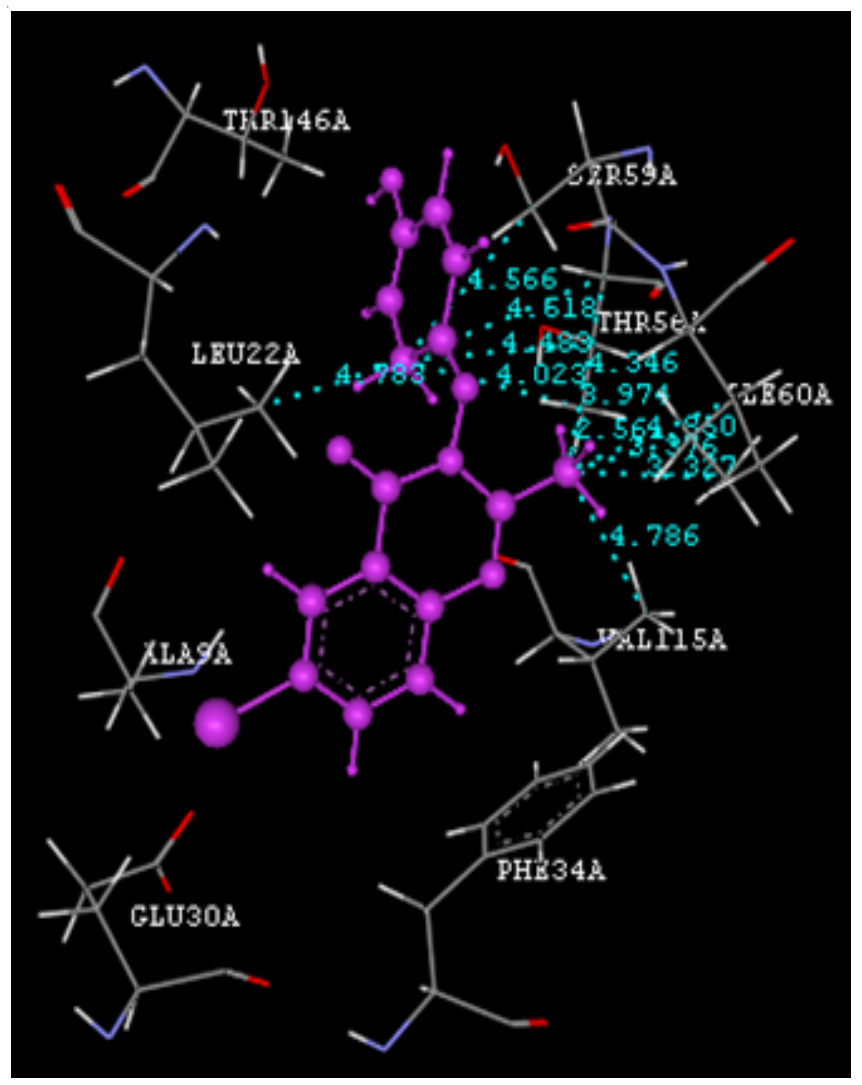

Fig. 1. Binding interaction pose of SM-16

Chemistry: The synthesized quinazolinone Schiff base and metal complexes are solid, gray in colour, stable and nonhygroscopic in nature. Intramolecular hydrogen bonding is responsible for stabilization of compounds. Ligand metal complexes are found to be soluble in methanol, ethanol, partly souble in water and insoluble in benzene, acetone and petroleum ether but soluble in DMSO, DMF and dioxin. These metal complexes melt between $230-290{ }^{\circ} \mathrm{C}$ and decomposes above $300{ }^{\circ} \mathrm{C}$. Result of physiochemical properties were given in Table-4.

TABLE-4

PHYSIOCHEMICAL PARAMETERS OF LIGANDS AND METAL COMPLEXES

\begin{tabular}{clccc}
\hline $\begin{array}{c}\text { Compound } \\
\text { codes }\end{array}$ & \multicolumn{1}{c}{ m.f. } & $\begin{array}{c}\text { m.w. } \\
(\mathrm{g})\end{array}$ & $\begin{array}{c}\text { Yield } \\
(\%)\end{array}$ & $\begin{array}{c}\text { m.p. } \\
\text { uncorrected } \\
\left({ }^{\circ} \mathrm{C}\right)\end{array}$ \\
\hline MS-02 & $\mathrm{C}_{22} \mathrm{H}_{16} \mathrm{BrO}_{2} \mathrm{~N}_{3}$ & 433.04 & 78 & $180-182$ \\
MS-04 & $\mathrm{C}_{22} \mathrm{H}_{16} \mathrm{BrON}_{3} \mathrm{~S}$ & 450.35 & 65 & $190-192$ \\
MS-09 & $\mathrm{C}_{16} \mathrm{H}_{13} \mathrm{O}_{2} \mathrm{~N}_{3}$ & 279.29 & 72 & $240-242$ \\
MS-10 & $\mathrm{C}_{16} \mathrm{H}_{12} \mathrm{BrO}_{2} \mathrm{~N}_{3}$ & 358.19 & 68 & $205-207$ \\
MS-11 & $\mathrm{C}_{16} \mathrm{H}_{13} \mathrm{ON}_{3} \mathrm{~S}$ & 295.36 & 65 & $175-177$ \\
MS-12 & $\mathrm{C}_{16} \mathrm{H}_{12} \mathrm{BrN}_{3} \mathrm{OS}$ & 374.25 & 62 & $245-247$ \\
SM-16 & $\mathrm{C}_{17} \mathrm{H}_{15} \mathrm{Cl}_{2} \mathrm{ON}_{3} \mathrm{OPt}$ & 575.37 & 65 & $255-257$ \\
SM-27 & $\mathrm{C}_{22} \mathrm{H}_{16} \mathrm{BrCl}_{2} \mathrm{~N}_{3} \mathrm{OPtS}$ & 716.33 & 62 & $265-267$ \\
SM-31 & $\mathrm{C}_{16} \mathrm{H}_{13} \mathrm{Cl}_{2} \mathrm{O}_{2} \mathrm{~N}_{3} \mathrm{Pt}$ & 545.28 & 65 & $240-242$ \\
SM-36 & $\mathrm{C}_{16} \mathrm{H}_{13} \mathrm{Cl}_{2} \mathrm{~N}_{3} \mathrm{OPtS}$ & 561.34 & 66 & $220-222$ \\
SM-37 & $\mathrm{C}_{16} \mathrm{H}_{13} \mathrm{BrCl}_{2} \mathrm{~N}_{3} \mathrm{OPtS}$ & 641.25 & 63 & $240-242$ \\
\hline
\end{tabular}

Synthesis: Molecules with higher docking scores were prioritized for synthesis. Prioritized molecules were synthesized using multi component reaction and one pot reaction. All molecules were characterized by IR, NMR, FESEM and XRD techniques.

\section{Characterization}

IR spectra: All the complexes show bands in the region 3414-3484 $\mathrm{cm}^{-1}$ due to $\mathrm{N}-\mathrm{H}$ stretching of amine; complex formation was only done on amine group due to greater reactivity as compared to $\mathrm{OH}$ group. Stretching of $=\mathrm{CH}_{2}$ observed in region 1654-1614 $\mathrm{cm}^{-1}$, N-N stretching frequencies of hydrazine was observed in region $950-900 \mathrm{~cm}^{-1}$; which confirms the bidentate bridging of hydrazine group. O-H stretching was observed in region of 3684-3600 and 1540-1500 $\mathrm{cm}^{-1}$ region showed asymmetric vibration in the molecules. The absorption band of $-\mathrm{CH}=\mathrm{N}$ - (azomethine nitrogen) was observed in region $1660-1620 \mathrm{~cm}^{-1}$.

XRD: Isomorphism among the series of metal ligand complex was confirmed by X-ray pattern, which is superimposable in nature. XRD powder pattern peaks for $\mathrm{Pt}(\mathrm{II})$ complexes are shown in Supplementary material indicate the semi crystalline nature of the compound. The highest intensity peak was evaluated at $3.20635^{\circ}$ with $27.281 \AA$ d-spacing values. The crystalline nature of the complex was investigated by XRD data, which indicates that the complexes are crystalline in nature.

FESEM: This method is basically used for quantification analysis of metals in synthesized complex. FESEM method quantified approximately $70 \%$ of $\mathrm{Pt}(\mathrm{II})$ present in synthesized complexes. Other elements were also quantified by this technique as shown in Table-5 and spectra in Fig. 2, respectively.

TABLE-5

FESEM RESULTS OF METAL COMPLEX (wt \%)

\begin{tabular}{cccccc}
\hline Element & SM-16 & SM-27 & SM-31 & SM-36 & SM-37 \\
\hline $\mathrm{Br}$ & - & - & - & 20.88 & 33.6 \\
$\mathrm{C}$ & 7.96 & 4.41 & 8.72 & 28.13 & 19.44 \\
$\mathrm{Pt}$ & 11.61 & 2.09 & 14.68 & 5.88 & 7.53 \\
$\mathrm{Cl}$ & - & - & 47.7 & 6.29 & 4.07 \\
$\mathrm{~N}$ & 8.95 & 51.46 & 2.7 & 4.46 & 3.66 \\
$\mathrm{O}$ & 36.07 & - & 1.56 & 11.42 & 17.91 \\
$\mathrm{~S}$ & 13.87 & 20.13 & - & - & 2.19 \\
\hline
\end{tabular}

NMR: In the spectra of ligand, peak at 8.5-7.9 ppm (singlet, $\mathrm{H}, \mathrm{Ar}-\mathrm{H}) ; 7.2 \mathrm{ppm}$ (Ar-H); 4 ppm (singlet, $\mathrm{OH}$ ); 8.7 ppm (singlet, Ar-H); 3.5 (singlet, $\mathrm{C}-\mathrm{H}$ ). This high value is due to strong electronegative atom attached directly, thus deshielding the proton by attracting electro density towards itself. Some other characteristic peak showed at $1.5 \mathrm{ppm}$ ( singlet, $\mathrm{CH}_{3}$ ), hydroxyl proton at 3.5 (singlet, $\mathrm{OH}$ ), amine proton at 10.8 ppm (singlet, $\mathrm{NH}$ ). All characterization data of synthesized compounds showed the confirmation of prioritized compounds.

in vitro Cell line testing of synthesized compounds: Cytotoxicity study was performed on ten cell lines. Compound SM-37, SM-27, SM-31 were found moderately active against HeLa, SK-OV-3 and KB cell line respectively where adiramycin used as standard. Compound SM-31 was active against all ten cell line but highly active against KB and SK- 

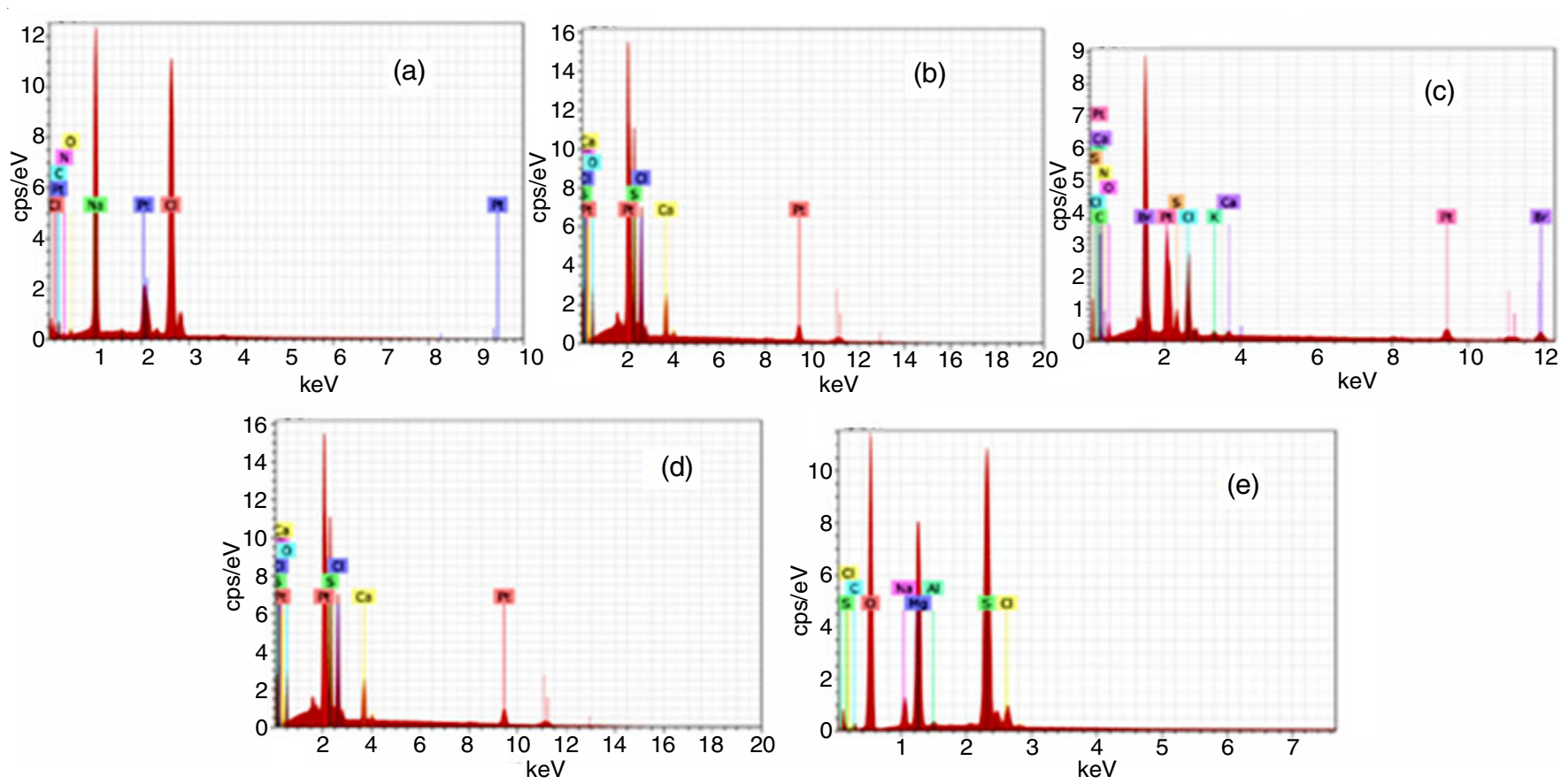

Fig. 3. FESEM spectra of (a) SM-31, (b) SM-36, (c) SM-37, (d) SM-16, (e) SM-27

OV-3 cell line. From the result of cell line studies, it is found that compound SM-27, SM-31 and SM-37 were found moderately active cytotoxic agents. The details of cytotoxicity study are given in Table-6.

\begin{tabular}{|c|c|c|c|c|c|c|c|}
\hline \multirow{3}{*}{ Cell line } & \multicolumn{5}{|c|}{$\begin{array}{c}\text { TABLE-6 } \\
\text { in vitro CYTOTOXICITY RESULTS OF METAL COMPLEXES }\end{array}$} & & \\
\hline & \multicolumn{7}{|c|}{$\mu$ Molar drug concentrations calculated } \\
\hline & Conc. of drug & MS-27 & MS-37 & SM-31 & SM-36 & SM-16 & ADR \\
\hline \multirow{3}{*}{$\mathrm{HeLa}$} & $\mathrm{LC}_{50}$ & $>100$ & $>100$ & $>100$ & $>100$ & $>100$ & $<0.1$ \\
\hline & TGI & $>100$ & $>100$ & $>100$ & $>100$ & $>100$ & $<0.1$ \\
\hline & $\mathrm{GI}_{50} *$ & $>100$ & 53.2 & 55.4 & $>100$ & 79.5 & $<0.1$ \\
\hline \multirow{3}{*}{ MCF-7 } & $\mathrm{LC}_{50}$ & $>100$ & $>100$ & $>100$ & $>100$ & $>100$ & 80.3 \\
\hline & TGI & $>100$ & $>100$ & $>100$ & $>100$ & $>100$ & $<0.1$ \\
\hline & $\mathrm{GI}_{50} *$ & $>100$ & $>100$ & 57.8 & $>100$ & $>100$ & $<0.1$ \\
\hline \multirow{3}{*}{ A-549 } & $\mathrm{LC}_{50}$ & $>100$ & $>100$ & $>100$ & $>100$ & $>100$ & $>100$ \\
\hline & TGI & $>100$ & $>100$ & $>100$ & $>100$ & $>100$ & 97 \\
\hline & $\mathrm{GI}_{50} *$ & $>100$ & 98.4 & 54.7 & $>100$ & 74.9 & 0.1 \\
\hline \multirow{3}{*}{ SK-MEL-2 } & $\mathrm{LC}_{50}$ & $>100$ & $>100$ & $>100$ & $>100$ & $>100$ & 70.5 \\
\hline & TGI & $>100$ & $>100$ & $>100$ & $>100$ & $>100$ & 27.1 \\
\hline & $\mathrm{GI}_{50} *$ & $>100$ & 93.3 & 73.2 & $>100$ & $>100$ & $<0.1$ \\
\hline \multirow{3}{*}{ НCT-15 } & $\mathrm{LC}_{50}$ & $>100$ & $>100$ & $>100$ & $>100$ & $>100$ & $>100$ \\
\hline & TGI & $>100$ & $>100$ & $>100$ & $>100$ & $>100$ & 62.9 \\
\hline & $\mathrm{GI}_{50} *$ & $>100$ & $>100$ & 61.5 & $>100$ & 77.2 & 3.2 \\
\hline \multirow{3}{*}{ DU-145 } & $\mathrm{LC}_{50}$ & $>100$ & $>100$ & $>100$ & $>100$ & $>100$ & $>100$ \\
\hline & TGI & $>100$ & $>100$ & $>100$ & $>100$ & $>100$ & 49.32 \\
\hline & $\mathrm{GI}_{50} *$ & $>100$ & $>100$ & 59.9 & $>100$ & $>100$ & $<0.1$ \\
\hline \multirow{3}{*}{ K-562 } & $\mathrm{LC}_{50}$ & $>100$ & $>100$ & $>100$ & $>100$ & $>100$ & $<0.1$ \\
\hline & TGI & $>100$ & $>100$ & $>100$ & $>100$ & $>100$ & $<0.1$ \\
\hline & $\mathrm{GI}_{50} *$ & $>100$ & 61.9 & 55.7 & 84.8 & 75.9 & $<0.1$ \\
\hline \multirow{3}{*}{$\mathrm{SiHa}$} & $\mathrm{LC}_{50}$ & $>100$ & $>100$ & $>100$ & $>100$ & $>100$ & $<0.1$ \\
\hline & TGI & $>100$ & $>100$ & $>100$ & $>100$ & $>100$ & $<.01$ \\
\hline & $\mathrm{GI}_{50} *$ & $>100$ & $>100$ & 84 & $>100$ & $>100$ & $<0.1$ \\
\hline \multirow{3}{*}{$\mathrm{KB}$} & $\mathrm{LC}_{50}$ & $>100$ & $>100$ & $>100$ & $>100$ & $>100$ & $<0.1$ \\
\hline & TGI & $>100$ & $>100$ & 99 & $>100$ & $>100$ & $<.01$ \\
\hline & $\mathrm{GI}_{50}$ * & $>100$ & 84.7 & 51.1 & $>100$ & $>100$ & $<0.1$ \\
\hline \multirow{3}{*}{ SK-OV-3 } & $\mathrm{LC}_{50}$ & $>100$ & $>100$ & $>100$ & $>100$ & $>100$ & 74.7 \\
\hline & TGI & $>100$ & $>100$ & 99 & $>100$ & $>100$ & 19.1781 \\
\hline & $\mathrm{GI}_{50} *$ & 75.7 & $>100$ & 51.1 & $>100$ & $>100$ & $<0.1$ \\
\hline
\end{tabular}

$\mathrm{LC}_{50}=$ Concentration of drug causing $50 \%$ cell kill; $\mathrm{GI}_{50} *=$ Concentration of drug causing $50 \%$ inhibition of cell growth; TGI $=$ Concentration of drug causing total inhibition of cell growth; ADR = Adriamycin, Positive control compound; NE = Non-evaluable data. Experiment needs to be repeated using different set of drug concentrations. 


\section{Conclusion}

In present work, 40 molecules were designed by docking simulation study. Molecules were prioritized with higher docking score and compared with methotrexate as standard. Interaction analysis study revealed binding affinity of molecule with DHFR receptor. Prioritized molecules were synthesized by bromination, esterification and cyclization and multi component reaction. IR, NMR, XRD and FESEM technique confirmed the formation of Schiff base and their platinum metal complexes. XRD spectra showed the crystalline nature of metal complex as well as FESEM shows quantification of metal and other elements. On the basis of in vitro cytotoxicity studies, synthesized compounds SM-27 (75.7 $\mu$ Molar), SM-37 (53.2 $\mu$ Molar) and SM-31 (51.1 $\mu$ Molar) were found to possess moderate cytotoxic activity. Interestingly, the cell line studies identified SM-31 as active against the panel of all cell lines. This could serve as a lead compound, which needs to be further optimized for cytotoxic activity. Thus, present work describes the design of platinum metal complexes of quinazolinone Schiff bases against DHFR as target through in silico studies. Their potential as DHFR inhibitors needs to be further explored through enzyme based assays.

\section{ACKNOWLEDGEMENTS}

The authors acknowledge Indian Council for Medical Research (ICMR), a constituent of Ministry of Health and Family Welfare, New Delhi, autonomous for Medical Research in India for funding grant number 55/38/2011-BMS and Savitribai Phule University, Pune, India for characterization of synthesized molecules.

\section{CONFLICT OF INTEREST}

The authors declare that there is no conflict of interests regarding the publication of this article.

\section{REFERENCES}

1. A.G. Nerkar and M. Sahu, J. Pharm. Pharm. Sci., 6, 509 (2014).

2. National Cancer Control Programmes, Policies and Managerial Guidelines, World Health Organization, Geneva, edn 2 (2002).

3. K.A. Dinshaw, D.N. Rao and B. Ganesh, Tata Memorial Hospital Cancer Registry Annual Report, Mumbai, India (1999).

4. H.-L. Ng, X. Ma, E.-H. Chew and W.-K. Chui, J. Med. Chem., 60, 1734 (2017); https://doi.org/10.1021/acs.jmedchem.6b01253.
5. J. Jolivet, K.H. Cowan, G.A. Curt, N.J. Clendninn and B.A. Chabner, N. Engl. J. Med., 309, 1094 (1983); https://doi.org/10.1056/NEJM198311033091805.

6. Y. Takemura, H. Kobayashi and H. Miyachi, Anticancer Drugs, 10, 677 (1999); https://doi.org/10.1097/00001813-199908000-00008.

7. N. Gonen and Y.G. Assaraf, Drug Resist. Updat., 15, 183 (2012); https://doi.org/10.1016/j.drup.2012.07.002.

8. E. Hamel, C.M. Lin, J. Plowman, H.-K. Wang, K.-H. Lee and K. D. Paull, Biochem. Pharmacol., 51, 53 (1996); https://doi.org/10.1016/0006-2952(95)02156-6.

9. K.B. Gudasi, S.A. Patil, M.V. Kulkarni and M. Nethaji, Transition Met. Chem., 34, 325 (2009); https://doi.org/10.1007/s11243-009-9198-8.

10. N. Farrell, Drugs Chemother Agents, 11, 809 (1989).

11. P.R. Mitchell and H. Sigel, Eur. J. Biochem., 88, 149 (1978); https://doi.org/10.1111/j.1432-1033.1978.tb12432.x.

12. http://nihserver.mbi.ucla.edu/SAVES.

13. H.M. Berman, Nucleic Acids Res., 28, 235 (2000); https://doi.org/10.1093/nar/28.1.235.

14. N.C. Desai, A. Dodiya, N. Shihory, J. Saudi Chem. Soc., 17, 259 (2013); https://doi.org/10.1016/j.jscs.2011.04.001.

15. A.S. Wheeler and W.M. Oates, J. Am. Chem. Soc., 32, 770 (1910); https://doi.org/10.1021/ja01924a009.

16. A.G. Nerkar, A.K. Saxena, S.A. Ghone and A.K. Thaker, E-J. Chem., 6(s1), S97 (2009); https://doi.org/10.1155/2009/506576.

17. K.T. Potts, M. Cipullo, P. Ralli and G. Theodoridis, J. Am. Chem. Soc., 103, 3584 (1981); https://doi.org/10.1021/ja00402a061.

18. K.S. Prasad, L.S. Kumar, S. Chandan, H.D. Revanasiddappa and B. Vijaya, Anal. Univ. Bucuresti Chim., 20, 7 (2011).

19. J. Barretina, G, Caponigro, N. Stransky, K. Venkatesan, A.A. Margolin, S. Kim, C.J. Wilson, J. Lehár, G.V. Kryukov, D. Sonkin, A. Reddy, M. Liu, L. Murray, M.F. Berger, J.E. Monahan, P. Morais, J. Meltzer, A. Korejwa, J. Jané-Valbuena, F.A. Mapa, J. Thibault, E. Bric-Furlong, P. Raman, A. Shipway, I.H. Engels, J. Cheng, G.K. Yu, J. Yu, P. Aspesi, Jr., M. de Silva, K. Jagtap, M.D. Jones, L. Wang, C. Hatton, E. Palescandolo, S. Gupta, S. Mahan, C. Sougnez, R.C. Onofrio, T. Liefeld, L. MacConaill, W. Winckler, M. Reich, N. Li, J.P. Mesirov, S.B. Gabriel, G. Getz, K. Ardlie, V. Chan, V.E. Myer, B.L. Weber, J. Porter, M. Warmuth, P. Finan, J.L. Harris, M. Meyerson, T.R. Golub, M.P. Morrissey, W.R. Sellers, R. Schlegel and L.A. Garraway, Nature, 483, 603 (2012); https://doi.org/10.1038/nature11003.

20. A. Monks, D. Scudiero, P. Skehan, R. Shoemaker, K. Paull, D. Vistica, C. Hose, J. Langley, P. Cronise, A. Vaigro-Wolff, M. Gray-Goodrich, H. Campbell, J. Mayo and M. Boyd, J. Natl. Cancer Inst., 83, 757 (1991); https://doi.org/10.1093/jnci/83.11.757.

21. P. Skehan, R. Storeng, D. Scudiero, A. Monks, J. McMahon, D. Vistica, J.T. Warren, H. Bokesch, S. Kenney and M.R. Boyd, J. Natl. Cancer Inst., 82, 1107 (1990); https://doi.org/10.1093/jnci/82.13.1107. 